\title{
Experimental Rigs for Wheel /Rail Contact Research
}

Juraj Gerlici ${ }^{1}$, Mykola Gorgunov ${ }^{2}$, Kateryna Kravchenko ${ }^{1}$, Alexander Kostyukevich ${ }^{2}$, Olena Nozhenko ${ }^{1}$, Tomáš Lack ${ }^{1}$ ${ }^{1}$ Department of Transport and Handling Machines, Faculty of Mechanical Engineering, University of Žilina, Univerzitná 1, 01026 Žilina. Slovak Republic. E-mail: juraj.gerlici@fstroj.uniza.sk, kateryna.kravchenko@fstroj.uniza.sk, olena.nozhenko@fstroj.uniza.sk, tomas.lack@fstroj.uniza.sk

${ }^{2}$ Department of Rail Transport, Institute of Transport and Logistics, Volodymyr Dahl East Ukrainian National University, Central Avenue 59a, 93400 Sewerodonetsk. Ukraine. E-mail: gn0255@mail.ru, a.i.kostyukevich@gmail.com

The article discusses the problem and importance of the study of the parameters of interaction between the wheel and the rail. The analysis of the test rig equipment for conducting research was carried out. Conventionally, the methods of conducting research are divided into 3 groups: physical and mathematical models, full-scale test rigs, field tests. Technical solutions for the modernization of the rig equipment of different types are proposed and the results of experimental studies using some of them are presented. For the approximation of rig equipment to the real conditions of operation it is proposed to cool the rail rollers through the use of the Ranque-Hilsch tube; to simulate the stiffness of the track on the rig it is effective to use leaf springs. Tests on a friction machine showed the effectiveness of sand electrification when supplying it into the contact of tribosystem.

Keywords: Rolling Rigs, Rail Rollers, Wheelset, Brake System, Adhesion

\section{Acknowledgements}

The research was conducted at the Department of Transport and Handling Machines of the Faculty of Mechanical Engineering of the University of Žilina by the National Scholarship Programme of the Slovak Republic for the Support of Mobility of Students, PhD Students, University Teachers, Researchers and Artists. The topic of the research is "Increased reliability and safe operation of trains using the innovative technical solutions in heavily loaded tribological contacts "rail track - rolling stock - contact network".

\section{References}

[1] BOSSO, N., SPIRYAGIN, M., GUGLIOTTA, A., SOMÀ, A. (2013). Mechatronic Modeling of Real-Time Wheel /Rail Contact, Springer, Berlin, 132 p.

[2] GORBUNOV M., KOSTYUKEVICH A., KRAVCHENKO K., KOVTANETS M. (2010). The effect of the electrification of sand on the interaction off riction in tribological contact. Transport Problem International Scientific Journal, Volume 6, Issue 4, Polsha, pp. 423 - 431.

[3] KRAVCHENKO K. (2009). Improvement of tester-measuring complex for research of coupling of wheel with rail. Journal of East Ukrainian National University named after Vladimir Dal. Scientific journal - Electronic scientific specialized edition, № 4E, http://www.nbuv.gov.ua/e-journals/vsunud/2009-4E/09keaksr.htm

[4] LUZHNOV Y. (2003). Adhesion of wheels with rails (nature and regularity). Intext, Moskow, 144 p.

[5] KOSTYUKEVICH, A. (2011). Overview of equipment used for the experimental study of contact frictional properties of «wheel / rail». Scientific news of Dahl university, № 3, Severodoneck.

[6] LIU, B. (2016). Study of rail vehicle dynamics and wheel /rail contact using full-scale roller rigs, Doctoral Dissertation, Politecnico di Milan, Milan, $103 \mathrm{p}$.

[7] ZHANG, W., CHEN, J., WU, X., JIN, X. (2002). Wheel/rail adhesion and analysis by using full scale roller rig. Wear, 253, pp. $82-88$.

[8] GERLICI, J., LACK, T., HARUŠINEC, J. (2014). Rail vehicles wheels and brake blocks wear laboratory test stand utilization. Prace Naukowe. Transport: Analiza i ocena elementów systemów transportowych, 101, pp. 2132.

[9] ŠŤASTNIAK, P. (2015). Wagon Chassis Frame Design with Adaptable Loading Platform. In: Manufacturing technology, Vol. 15, No. 5, pp. 935 - 940.

[10] DIŽO, J., (2015). Evaluation of Ride Comfort for Passengers by Means of Computer Simulation. In: Manufacturing technology, Vol. 15, No. 1, pp. 8 - 14 .

[11] DIŽO J., HARUŠINEC J., BLATNICKÝ M. (2015). Multibody System of a Rail Vehicle Bogie with a Flexible Body. In: Manufacturing technology, Vol. 15, No. 5, pp. 781 - 788. 
[12] MAŇUROVÁ, M., SUCHÁNEK, A. (2016). Determination of Stiffness of Triple Spring Built in a Bogie of Rail Vehicle. In: Manufacturing technology, Vol. 16, No. 2, pp. 390 - 396.

[13] SUCHÁNEK, A., HARUŠINEC, J. (2015). The Downhill Braked Railway Wheel Structural Analysis by Means of the ANSYS Multiphysics Program System Package. In: Manufacturing technology, Vol. 15, No. 5, pp. 945 950.

\section{Paper number: M2016168}

Copyright $\odot$ 2016. Published by Manufacturing Technology. All rights reserved. 